\title{
ANALISIS RUNTUHNYA ISLAM DI SPANYOL
}

\author{
Romdloni ${ }^{1}$ \\ Dosen STKIP Nurul Huda OKU Timur \\ Email: romdlony29@gmail.com
}

\begin{abstract}
ABSTRAK
Spanyol merupakan tempat yang paling utama bagi Eropa dalam penyerapan ilmu pengetahuan yang dikembangkan umat Islam di sana serta peradabannya, baik dalam hubungan politik, sosial, maupun ekonomi dan peradaban antar negara. Orang-orang Eropa menyaksikan kenyataan bahwa Spanyol berada di bawah kekuasaan Islam jauh meninggalkan negara-negara tetangganya di Eropa, terutama dalam bidang pemikiran dan sains. Di samping itu juga peradabannya yakni bangunan-bangunan fisik lainya.
\end{abstract}

\section{PENDAHULUAN}

Setelah berakhirnya periode klasik Islam, ketika Islam mulai memasuki masa kemunduran, Eropa bangkit dari keterbelakangannya. Kebangkitan itu bukan saja terlihat dalam bidang politik dengan keberhasilan Eropa mengalahkan kemajuankemajuan Islam dan bagian dunia lainnya, tetapi terutama dalam bidang ilmu pengetahuan dan teknologi. Bahkan, kemajuan dalam bidang ilmu dan teknologi itulah yang mendukung keberasilan politiknya.

Kemajuan-kemajuan Eropa ini tidak bisa dipisahkan dari pemerintahan Islam di Spanyol. Dari Islam Spanyol di Eropa banyak menimba ilmu, pada periode klasik, ketika Islam mencapai masa keemasannya, Spanyol merupakan pusat peradaban Islam yang sangat penting, menyaingi Baghdad di timur. Ketika itu, orang-orang Eropa Kristen banyak belajar di perguruan-perguruan tinggi Islam di sana. Islam menjadi guru bagi orang Eropa. Karena itu, kehadiran Islam di Spanyol banyak menarik perhatian para sejarawan.

Sejarah mencatat bahwa peradaban Islam pernah mencapai puncak kejayaannya, berkat adanya ketekunan pemeluk Islam dalam mencari dan menyebarkan ilmu pengetahuan. Hal tersebut di karenakan adanya dorongan yang kuat dari ajaran Islam itu sendiri, yang dapat membuat pemeluknya lebih giat dalam menggali dan menemukan sesuatu yang baru dan berguna bagi umat manusia. Dengan adanya kegiatan penerjemahan buku-buku berbahasa Arab hasil karya para pemikir Islam ke dalam bahasa-bahasa Eropa, maka terbukalah pintu ilmu pengetahuan di Eropa.

1 Dosen Prodi PAI STKIP Nurul Huda OKU Timur, makalah ini disajikan saat penulis masih menempuh studi S2 di UIN Maulana Malik Ibrahim Malang. 


\section{SEJARAH MASUKNYA ISLAM DI SPANYOL}

Dalam sejarah ilmu pengetahuan dan peradaban Islam, tanah Spanyol lebih banyak di kenal dengan nama Andalusia, yang di ambil dari sebutan tanah semenanjung lberia. Julukan Andalusia berasal dari kata vandalusia, yang artinya negeri bangsa vandal, karena bagia selatan semenanjung ini pernah di kuasai oleh bangsa vandal sebelum mereka di kalahkan oleh bangsa gothia barat pada abad V. daerah ini di kuasai oleh Islam setelah penguasa bani umayyah merebut tanah semenanjung ini bangsa gothik barat pada masa khalifah Al-Walid Ibn Abdul Malik. ${ }^{2}$

Spanyol di duduki umat Islam pada zaman khalifah Al-Walid (705-715), salah seorang khalifah dari bani umayyah yang berpusat di damaskus. Sebelum meneklukkan Spanyol, umat Islam telah mengusai afrika utara dan menjadikannya sebagai salah satu provinsi dari dinasti umayyah. Penguasaan sepenuhnya atas afrika utara itu terjadi dizaman khalifah Abdul Malik (685-705) khalifah Abdul Malik mengangkat Hasan Bin Nu'man Al-Ghassani menjadi gubenur di daerah itu. Pada masa khalifah Al-Khalifah AlWalid, Hasan bin Nu'man sudah digantikanoleh Musa Bin Nushair.di zaman Al-Walid itu, Musa bin Nushair memperluas wilayah kekuasaannya dengan menduduki aljazair dan maroko. Selain itu, ia juga menyempurnakan penaklukan ke daerah-daerah bekas kekuasaan bangsa barbar di pegunungan-pegunungan, sehingga mereka menyatakan setia dan berjanji tidak akan membuat kekacauan seperti yang pernah mereka lakukan sebelumnya.

Sebelum dikalahkan dan kemudian di kuasai Islam, di kawasan ini terdapat kantung-kantung yang menjadi basis kekuasaan kerajaan romawi, yaitu kerajaan gothik. Kerajaan ini sering menghasut penduduk agar membuat kerusuhan dan menentang kekuasaan Islam. Setelah kawasan ini betul-betul dapat di kuasai, umat Islam mulai memusatkan perhatiannya untuk menaklukkan Spanyol. Dengan demikian, afrika utara menjadi batu loncatan bagi kaum muslimin dalam penaklukan wilayah Spanyol. ${ }^{3}$

Sukses Thariq Bin Ziyad di masa Al-Walid (Daulat Umayyah-Damaskus) diikuti oleh Abd Al-Rahman Al-Dakhil (penguasa pertama Daulat Umayyah-Spanyol), yang berusaha menata sistem pemerintahan. Ia melihat masyarakat Spanyol adalah masyarakat heterogen, baik berdasarkan strata sosial, suku, ras, maupun agama. Dia memiliki tentara yang terorganisir dengan baik yang jumlahnya tidak kurang dari 40.000 tentara bayaran Barbar dan juga membangun angkatan laut yang kuat. Gebrakan

2 Prof.Dr Suwito, Sejarah SoSial Pendidikan Islam, Kencana, Jakarta: 2005, hal 110.

${ }^{3}$ Samsul munir amin, Islam Sejarah Peradaban, Sinar Grafika Offset, Jakarta : 2009, hal 161-162 
lain yang dilakukannya adalah mendirikan mesjid agung Cordova dan sekolah-sekolah di kota-kota besar di Spanyol. ${ }^{4}$

Dalam proses penaklukan Spanyol terdapat tiga pahlawan Islam yang dikatakan paling berjasa memimpin satuan-satuan pasukan ke sana. mereka adalah Tharif Ibn Malik, Thariq Ibn Ziyad, dan Musa Ibn Nushair. Tharif dapat di sebut sebagai perintis dan penyelidik. Ia menyeberangi selat yang berada di antara maroko dan benua Eropa itu dengan satu pasukan perang, 500 orang di antaranya adalah tentara berkuda, mereka menaiki empat buah kapal yang disediakan oleh Julian. Dalam penyerbuan itu Tharif tidak mendapat perlawanan yang berarti. Ia menang dan kembali ke afrika utara membawa harta rampasan yang tidak sedikit jumlahnya. ${ }^{5}$ didorong oleh keberhasilan Tharif dan gemelut yang terjadi dalam tubuh kerajaan visigothic yang berkuasa di Spanyol pada saat itu, serta dorongan yang besar untuk memperoleh harta rampasan perang, Musa Ibn Nushair pada tahun 711 M mengirim pasukan ke Spanyol sebanyak 7000 orang di bawah pimpinan Thariq Ibn Ziyad. ${ }^{6}$

\section{PERKEMBANGAN POLITIK ISLAM DI SPANYOL}

Masa kekuatan Islam di Spanyol di mulai semenjak tahun $711 \mathrm{M}$, ketika Thariq Ibn Ziyad mampu menghancurkan pasukan Goth dan mengusai kota Toledo dan berakhir pada 1492, selama lebih dari tujuh abad umat Islam memerintah Spanyol dalam bentuk pemerintahan yang berada. Sejarah pemerintahan terbagi menjadi enam periode, yaitu;

1. Pemerintahan Perwalian

Periode pemerintahan para wali di Spanyol selama 44 tahun (711-755 M) ini kondisi politik negeri Spanyol belum stabil, karena banyaknya gangguan baik datang dari dalam maupun gangguan dari luar. Gangguan dari dalam diakibatkan oleh perselisihan diantara elite penguasa terutama akibat perbedaan etnis dan golongan. Perbedaan etnis ini terutama terjadi antara suku Barber dan Arab. Perbedaanperbedaan ini sering menimbulkan konfik politik, terutama pada saat tidak ada figure yang kuat.7 dalam sejarah pemerintahan perwalian ini terjadi banyak pergantian kepemimpinan, sampai sebanyak dua puluh kali, padahal periode ini hanya berlangsung kurang dari setengah abad. Kondisi inilah yang menjadikan para wali hanya berkuasa sangat singkat dan sering memicu terjadinya perang saudara.

\footnotetext{
${ }^{4}$ http://fadliyanur.multiply.com/journal/item/34, Diakses tanggal 02 januari 2011.

${ }^{5}$ A. Syalabi, Sejarah Dan Kebudayaan Islam, Pustaka Alhusna: Jakarta, 1983, hal 154.

${ }^{6}$ Dr. Badri Yatim, sejarah peradaban islam, PT Rajagrafindo Persada, Jakarta, 2008, hal 89.

${ }^{7}$ Badri, op. cit., hal 94.
} 


\section{Pemerintahan Keamiran}

Periode ke Amiran (755-912 M) di mulai ketika Abd Al Rahman Al Dakhil berkuasa menjadi Amir (panglima atau gubenur) dengan tidak tunduk kepada pemerintah pusat yang sudah berpindah dari bani Ummayah kepada bani Abbasiyah, berpusat di Bagdad. Amir Abd Al Rahman keturunan bani Ummayah yang bergelar Al-Dakhil karena berhasil memasuki Spanyol pada tahun 138 H/ 755 M, lolos dari kerajaan bani Abbas yang menaklukkan damaskus.dengan berpindahnya kekuasan Islam dari bani Ummayah ke bani Abbasiyah, maka dia memproklamirkan diri menjadi penguasa dinasti Ummayah di Spanyol, pemerintahan keamiran di Spanyol di pimpin oleh Abd Rahman Al-Dakhil, Hisyam I, Hakam I, Abd Al Rahman Al Ausath, Muhammad Ibn Abd Al Rahman, Munzir Ibn Muhammad dan Abdullah Ibn Muhammad. Pada masa itu para amir mampu membangun peradaban sehingga masyarakat Islam di Spanyol memperoleh kesejahteraan dan kemajuan. ${ }^{8}$

3. Pemerintahan Kekhilafahan

Periode pemerintahan kekhilafahan (912-1013 M) di mulai semenjak pemerintahan Abd Al Rahman III yang bergelar Al-Nazir sampai munculnya Muluk AlThawaif (raja-raja kelompok) penggunaan gelar Al Nasir pada diri Abd Al Rahman mengikuti Trend saat itu bahwa seorang khalifah diangkat oleh golongan untuk membimbing masyarakat Islam menuju kebenaran. Dengan demikian mulai saat secara de facto dan de jure Abd Al Rahman menjadi khalifah atas seluruh umat Islam, tidak tunduk dan mengakui kekhalifahan Abbasiyah, seperti dinasti fatimiyah di mesir.

Periode ini, masyarakat Islam di Spanyol mencapai masa kejayaan, kesejahteraan dan kemakmuran sejajar dengan kejayaan yang dicapai Abbasiyah pada masa keemasannya. Abd Al Rahman Al Nasir mendirikan Universitas Cordova, perpustakannya memiliki koleksi ribuan buku. Hakam II juga gemar mengoleksi bukubuku dan mendirikan perpustakaan. Namun kejayaan dengan munculnya peradaban ini mulai redup ketika Hisyam yang menggantikan Hakam II naik tahta dalam usia sebelas tahun. Dalam beberapa tahun kemudian Negara yang tadinya sangat makmur, hancur dilanda kekacauan, sehingga pada tahun 1009 M khalifah Hisyam II mengundurkan diri. Upaya mempertahankan kekhilafahan tersebut terus dilakukan, akan tetapi beberapa orang yang dicoba untuk menduduki jabatan tersebut tidak ada yang mampu memperbaiki keadaan. Akhirnya pada tahun 1013 M, dewan menteri yang memerintah Cordova menghapus jabatan khalifah dan dimulailah wilayah Spanyol terbagi dan

${ }^{8}$ Ahmad Syalabi, Sejarah Kebudayaan Islam, Jakarta, UI Press, 1991, hal 67-74. 
terpecah atas beberapa Negara kecil yang menjadikan kota-kota tertentu sebagai pusat kekuasaannya. ${ }^{9}$

\section{Pemerintahan Al Muluk Al Thawaif}

Setelah hancurnya kekhalifahan Ummayah di Spanyol, Negara tersebut terpecah menjadi lebih dari tiga puluh Negara kecil da bawah pemerintahan raja-raja golongan di sebut Al Muluk Al Thawaif (1013-1086 M) yang menjadikan kota-kota tertentu menjadi pusat kekuasaannya. Periode ini, Negara Spanyol kembali menjadi ajang perebutan dan pertikaian di antara masyarakat Islam. Melihat kondisi lemah dan kacaunya pemerintahan Islam saat itu, di mulailah usaha kaum kristen untuk mengadakan penyerangan dan pengambil alihan wilayah tertentu dari kaum muslimin.

Dengan semangat untuk mempersatukan kerajaan Castile, Leon dan kerajaan Galicia pada tahun 1085 M Alfonso VI menaklukkan Teledo. Pengusaan awal atas Toledo ini merupakan awal pecahnya peperangan antara pihak muslim dan Kristen, karena Toledo sebagai pusat peradaban Islam telah jatuh ke tangan orang-orang Kristen. ${ }^{10}$

5. Pemerintahan Dinasti Murabitun Dan Muwahidun

Periode pemerintahan Murabitun dan Muwahidun (1086-1248 M) dinasti Murabitun masuk dan berkuasa di Spanyol (1086-1143 M) atas undangan penguasa Islam untuk mempertahankan karena mereka terdesak oleh penyerangan yang di lakukan pihak Kristen. Pemerintahan Murabitun di Spanyol di bangun atas dasar koalisi antara militer yang memerintah kota-kota dengan ulama. Namun demikian masih terjadi permusuhan-permusuhan bahkan pemberontakan seperti yang dilakukan kaum sufi yang mengepalai pemberontakan seperti yang di lakukan kaum sufi yang mengepalai pemberontakan di silves dan niebla, kaum ulama mengepalai pemberontakan di cordova dan Valencia yang menjadi penyebab kehancuran Murabitun.

Muwahidun (1146-1135 M) mengantikan kekuasaannya atas Afrika Utara sampai Spanyol dinasti ini datang ke Spanyol atas komando Abd Mun'im, mereka merebut Sevilla dan Cordova tahun 1149 dan menguasai seluruh wilayah muslim Spanyol pada tahun $1172 .{ }^{11}$ setelah berhasil menguasai Spanyol dan memukul mundur orang Kristen, tetap saja dinasti ini dalam situasi dirongrong oleh pasukan Kristen, mula-mula pasukan gabungan Leon, Castile, Navarre dan Aragon dapat memukul mundur pasukan Muwahidun pada tahun 1212 dalam perang Las Navas De Tolosa. Kekalahan ini memunculkan keinginan raja-raja muslim untuk bangkit kembali tapi mereka tidak

\footnotetext{
${ }^{9}$ W Montgomery Watt, Kejayaan Islam. Yogya, Tiara Wacana, 1990, hal 217-218.

${ }^{10}$ Badri Yatim, op. cit., hal 98.

11 Ira M Lapidus, Sejarah Social Umat Islam, Jakarta Rajawali 1999, 590-591.
} 
mampu menghadapi gerakan Reconguesta yang di lancarkan pasukan Kristen. Kekuatan gabungan Leon dan Castile dapat menaklukan Codova (1236) dan Sevilla (1248), pasukan Aragon menaklukkan Valencia (1238) dan Murcia (1243). Dengan kekalahan ini, dinasti Muwahidun akhirnya meninggalkan Spanyol dan kembali ke afrika utara tahun 1235.12

\section{Pemerintahan Dinasti Bani Ahmar Di Granada}

Periode ini pemerintah Islam hanya berkuasa di Granada di bawah dinasti bani Ahmar, karena seluruh wilayah Spanyol telah direbut kembali oleh pasukan Kristen. Kemajuan besar dalam peradaban ini, runtuh setelah dinasti yang hanya berkuasa di wilayah kecil ini tidak mampu mencegah perebutan kekuasaan di kalangan pangeranya. Abu Abdullah Muhammad yang merasa di singkirkan karena tidak diberi wewenang menggantikan kedudukan orang tuanya menjadi amir di Granada, akhirnya Abu Abdullah memberontak. Setelah ayahnya terbunuh kekuasaan beralih ke Mahammad ibn Sa'ad. Abu Abdullah lalu meminta bantuan kepada Ferdinand dan Isabella. Mereka berhasil mengalahkan penguasa yang sah dan menjadikan Abu Abdullah naik tahta. Ketika kedua raja tersebut bersatu untuk merebut kekuasaan terakhir umat Islam di Granada. Abu Abdullah tidak kuasa menahan serangan tersebut pada tahun 1492. Kekalahan membuatnya hijrah ke afrika utara dan dengan demikian berakhirlah kekuasaan Islam di Spanyol. ${ }^{13}$

\section{PERKEMBANGAN PENDIDIKAN ISLAM DI SPANYOL}

Perkembangan pendidikan Islam di Spanyol meliputi perkembangan dari sisi institusinya maupun materi atau kurikulumnya. Pada masa pemerintahan Abdurahman Al-Dakhil memanfaatkan potensi ini dengan sebaik-baiknya bagi pengembangan ilmu pengetahuan. Adapun upayanya dalam mengembangkan pendidikan dan peradaban antara lain :

\section{Mendirikan Lembaga Pendidikan}

Ketika Islam berkuasa di Spanyol telah mendirikan madrasah-madrasah yang tidak sedikit jumlahnya guna menopang pengembangan pendidikannya. Madrasah-madrasah ini tersebar di seluruh daerah kekuasaan Islam, antara lain di qurthubah (cardova), isybiliah (Seville), thulaithilah (Toledo), gharnathah (Granada). ${ }^{14}$

\footnotetext{
12 Ahmad Syalabi, op. cit., hal 76.

${ }^{13}$ H. Taufiqurrahman, Sejarah Politik Masyarakat Islam, Bina Usaha Yogyakarta: 2001, hal 187.

14 Prof. Dr. H. Syamsul Nizar, Sejarah Pendidikan Islam Menelusuri Jejak Sejarah Era Rasullah Sampai Indonesia, Fajar Interpratama Offset, Jakarta : 2007, Hal 79-80.
} 
Untuk sekolah dasar, pendidikan Spanyol Islam menitik beratkan pada pendidikan agama yang meliputi: dasar-dasar agama dan sastra, sedangkan pada taraf berikutnya meningkat pada materi pendidikan ilmu-ilmu akal, seperti: filsafat, matematika, farmasi, kedokteran, pelayaran, fisika, seni arsitektur, geografi, ekonomi, serta pengembangan ilmu naqli ( ilmu-ilmu yang berkaitan dengan Al-Qur'an dan Hadist). ${ }^{15}$

Untuk pendidikan perguruan tinggi, khalifah Abdul Rahman III mencoba merintis dengan mendidikan universitas cordova sebagai ilmu pusat pengetahuan. Universitas ini mengambil tempat di sebuah masjid. Pada pemerintahan Al-Hakam II (961-976 M), universitas kemudian di perluas lokasinya, dan bahkan mendatangkan para profesor dari timur( Al-azhar dan nizhamiyah) sebagai dosen undangan untuk memberikan perkuliahan di Spanyol. untuk melaksanakan upaya ini, ia menyediakan berbagai fasilitas yang dapat menunjang kelancaran proses pendidikan, terutama bagi tenaga guru yang di datangkan dengan menyediakan berbagai hadiah untuk gaji atau honorer mereka. Langkah yang di ambil Al-Hakam II dalam memajukan pendidikan di Spanyol Islam, kemudian di ikuti oleh para penguasa sesudahnya. Bahkan di antara para penguasa ada yang menyiapkan istananya sebagai pusat pengkajian dan pengembangan ilmu pengetahuan, seperti kajian filsafat, ilmu pengetahuan, dan literature. ${ }^{16}$

Dalam menunjang pendidikanya, pendidikan Spanyol Islam memberlakukan kurikulum universitas dan komprehensif. Artinya menawarkan materi pendidikan agama dan umum secara integral pada setiap tingkatan pendidikannya, khususnya pendidikan tinggi. Indikasi dari kedalaman dan keluasan kurikulum Spanyol Islam waktu itu boleh jadi ditentukan konsekuensi-konsekuensi pratikal yang bermanfaat bagi kehidupan manusia, sehingga pola kurikulum yang diterapkan tidak bersifat fleksibel.17 Sedangkan metode pendidikan yang biasa di terapkan di Spanyol antara lain:

a. Metode pendidikan formal

Pendidikan ini guru (dosen) duduk di atas podium. Ia memberikan materi pelajaran khususnya pendidikan tinggi dengan membaca manuskrip-manuskrip. Setelah itu guru menerangkan secara jelas. Kemudian materi tersebut di diskusikan bersama. Para pelajar di berikan kebebasan untuk bertanya dan mengeluarkan pendapat, bahkan di perkenankan untuk berbeda pendapat dengan statemen yang di berikan gurunya, asal mereka dapat mengajukan bukti-bukti yang mendukung kebenaran pendapatnya. Kesimpulan dari diskusi tersebut kemudian mereka catat, khususnya pada materi yang

\footnotetext{
15 Ibid, . hal 81.

16 Ibid, hal 81.

17 Ibid,. hal 83.
} 
terbatas buku cetakannya. Dalam penyampaian materi seorang dosen di bantu oleh seorang asisten yang bertugas untuk membantu pelajar (mahasiswa) dalam memahami materi yang di pelajarinya. Guru (dosen) menggunakan tiga langkah dalam persentasinya yaitu menerangkan materi secara umum, agak singkat dan mendetail. Kemudian jika ada yang masih belum mengerti, guru (dosen) tidak segan-segan untuk mengulanginya kembali. Kemudian mahasiswa menghafalnya, mengulang lagi apa yang di hafalnya, dianalisis, dan diaplikasikan dalam kehidupan sehari-hari. ${ }^{18}$

b. Metode Pendidikan Nonformal

Metode pendidikan nonformal ini menggunakan metode halaqah. Guru mendiktekan (membacakan) sejumlah buku, dan kemudian menjelaskannya secara rinci. Diskusi seperti ini merupakan metode pengajaran yang telah membumi di Spanyol Islam. ${ }^{19}$

\section{Pengembangan Perpustakaan}

ibu kota juga memiliki sebuah perpustakaan paling besar. Al-hakam adalah seorang pencinta buku. Para pegawainya menjelajah semua toko buku di iskandariyah, damaskus. Dan Baghdad, untuk membeli atau menyalin berbagai naskah. Di ceritakan bahwa buku yang mereka peroleh berjumlah 400.000 judul dan 44 jilid katalog, dalam setiap jilid, 20 halaman khusus untuk karya-karya puisi. ${ }^{20}$

Ambisi untuk mendirikan perpustakan, bukan hanya di lakukan oleh para khalifah saja. Akan tetapi, ambisi tersebut juga telah di miliki oleh setiap masyarakat Spanyol Islam. Mereka mengoleksi berbagai buku bukan untuk kepentingan dirinya saja, akan tetapi ia wakafkan untuk dapat di manfaatkan oleh masyarakat umum, seperti yang dilakukan oleh Abdul Mutrif, seorang hakim di cordova. Ia telah mengoleksi berbagai buku-buku langka. Ia juga memperkerjakan enam orang karyawan untuk menyalin buku-buku tersebut sehingga dapat disebar luaskan pada masyarakat umum. ${ }^{21}$

Perkembang perpustakaan di Spanyol semakin hari semakin mengalami perkembangan akhirnya berdirilah perpustakaan khazanatul humits-tsani di Spanyol. Perpustakaan ini memiliki buku sebanyak 400.000 jilid. Di samping perpustakaanperpustakaan lain yang di dirikan oleh perorangan untuk dimanfaatkan secara umum, bahkan mereka berlomba-lomba untuk untuk mendirikanya. Kondisi ini pula yang ikut mendukung bagi pengembangan ilmu pengetahuan di Spanyol, sehingga dengan sekejap

\footnotetext{
18 Ibid, hal 84

19 Ibid,. hal 84.

${ }^{20}$ Philip K Hitti, History of the Arabs, PT Serambi Ilmu Semesta, Jakarta: 2010, hal 675.

21 Prof. Dr. H Samsul Nizar,. op. cit hal 85
} 
telah menyulap daerah Spanyol dari Negara yang kaya, makmur dan maju, di samping kemerdekaan ilmiah yang di kembangkan. Kondisi ini di terlihat dari peraturan yang berlaku saat itu. Ilmu pengetahuan bukan hanya milik orang merdeka, tetapi juga merupakan milik para budak. Hubungan yang harmonis ini menjadi daya penggerak tersendiri bagi kemajuan pendidikan yang di perkenalkan Spanyol Islam. ${ }^{22}$

\section{Kemajuan Intelektual}

Sejak pertama kali Islam di Spanyol hingga jatuhnya kerajaan Islam terakhir di sana sekitas tujuh setengah abad lamanya, Islam memainkan peranan yang besar, baik dalam bidang kemajuan intelektual ( filsafat, sains, bahasa, sastra, musik, kesenian ) ${ }^{\mathbf{2 3}}$

a. Filsafat

Perkembangan filsafat di Andalusia di mulai sejak abad ke-8 hingga abad ke-10. Manuskrip-manuskrip yunani telah diteliti dan diterjemahkan ke dalam bahasa Arab. Pada masa khalifah Abbasiyah, Al-Manshur (754-755) telah di mulai aktifitas penerjemahan hingga masa khalifah Al-Makmum (813-833 M) pada masanya banyak filsafat karya aristoteles yang di terjemahkan.

Tokoh utama dan pertama dalam sejarah filsafat Arab Spanyol adalah Abu Bakar Muhammad bin As-Sayigh yang di kenal dengan Ibnu Bajjah. Tokoh utama kedua adalah Abu Bakar bin Thufail, karyanya adalah hay bin yaqzhan. Tokoh filsafat Islam Spanyol lainnya adalah Ibnu Rusyd yang di Eropa terkenal dengan averros dari cordiva (11261198), pengikut aliran aristoteles. Di samping sebagai tokoh filsafat, ia juga dikenal sebagai ulama fiqih penulis bidayat Al-mujtahid. ${ }^{24}$

b. Sains

Sains yang terdiri dari ilmu-ilmu kedokteran, fisika, matematika, astronomi, kimia, botani, zoology, ilmu obat-obatan, juga berkembang dengan baik. Dalam bidang sejarah dan geografi, wilayah Islam bagian barat melahirkan banyak pemikir terkenal.

Tokoh sains dalam bidang astronomi, yaitu Abbas bin Farnas, Ibrahim bin yahya an-naqqash, ibnu Safar, Al-Bitruji, dalam bidang obat-obatan, antara lain ahmad bin iyas dari cordova, ibnu juljul, ibnu hazm, ibnu Abdurrahman bin Syuhaid, dalam bidang kedokteran yaitu Ummul Hasan Binti Abi Ja'far, seorang tokoh dokter wanita, dalam bidang geografi yaitu Ibnu Jubar dari Valencia, Ibnu Batuthah dari tagier. ${ }^{25}$

\footnotetext{
22 Ibid, hal 86.

23 Prof.Dr. Suwito, op.cit, hal 111.

${ }^{24}$ Samsul Munir Amin, op.cit,. hal 172-173.

25 Ibid, hal 173.
} 
c. Bahasa Dan Sastra

Pada masa Islam di Spanyol banyak yang ahli dan mahir dalam bahasa Arab, di antaranya: ibnu Sayyidih, Muhammad bin Malik, pengarang Alfiyah (tata bahasa Arab), Ibnu Khuruf, Ibnu Al-hajj, Abu Ali Al-Isybili, Abu Al-Hasan bin Usfur dan Abu Hayyan AlGharnathi.

Dalam bidang sastra banyak bermunculan, seperti Al-Aqd Al-Farid karya Ibnu Abd Rabbih, Adz Dzakirah fi Mahasin Ahl Al-Jazirah karya ibnu Bassam, kitab Al-Qalaid karya Al-Fath bin Khaqan.

d. Musik dan kesenian

Masa Islam di Spanyol sangat masyhur. Musik dan seni banyak memperoleh apresiasi dari para tokoh penguasa istana. Tokoh seni dan musik antara lain: Al-hasan bin Naïf yang mendapat gelar zaryab dia juga terkenal sebagai pencipta lagu-lagu. ${ }^{26}$

\section{Kemajuan Bidang Agama}

a. Tafsir

Salah satu mufasir yang terkenal dari Andalusia adalah Al-Qurtubi. Nama lengkapnya Abu Abdilah Muhammad bin Ahmad bin Abu Bakr bin Farh Al-Anshari AlKhazraji Al-Andalusi (wafat $1273 \mathrm{M}$ ) karyanya dalam bidang tafsir adalah Al-Jami'u li ahkam Al-Quran, kitab tafsir yang terdiri yang terdiri dari 20 jilid ini di kenal dengan nama tafsir Al-Qurtubi.

b. Fiqih

Dalam bidang fiqih, Spanyol Islam sebagai pusat penganut mazhab maliki. Dalam hal ini yang memperkenalkan mazhab maliki di Spanyol adalah Ziyad bin Abd ArRahman. Perkembangan selanjutnya di tentukan oleh ibn Yahya yang menjadi qadhi pada masa Hisam bin Abdurrahman. Para ahli lainnya Abu Bakar bin Quthiyah, Muniz bin Sa'id Al-Baluthi, Ibnu Rusyd, penulis kitab bidayah al-mujtahid Wa Nihayah AlMuqtasid, Asy-Syatibi, penulis buku Al-Muwafaqat fi Usul Asy-Syari'ah (usul fiqih), dan ibnu Hazm. ${ }^{27}$

\section{Kemajuan Dalam Bidang Arsitektur Bangunan}

Puncak kemegahan itu bukan hanya terlihat pada kebangkitan ilmu pengetahuan filsafat, seperti telah di uraikan di atas. Tetapi juga dapat disaksikan pada pembangunan sarana fisik yang amat mengagumkan. Pembangunan kota-kota yang indah, dihiasi dengan gedung-gedung bertingkat dengan gaya arsitek yang sangat artistik, monumen-

\footnotetext{
26 Ibid,. hal 174.
}

27 Ibid, hal 174. 
monumen dan taman-taman yang mempesona, serta ruas-ruas jalan yang teratur melingkari setiap sudut kota. ${ }^{28}$

Pembangunan bidang industri, seperti tekstil, logam, kayu, kulit dan industriindustri. Pada seperempat pertama abad ke 12 menjadikan Cordova sebagai salah satu kota industri terbesar pertama. Salah satu produk terpentingnya adalah kain sutra, yang diekspor besar-besaran ke wilayah timur tengah, Persia dan Mesopotamia.

Kota-kota besar di Spanyol hingga sekarang masih mewarisi sisa-sisa kebesaran peradaban kaum muslim Spanyol, yang di kenal dengan sebutan "bangsa moors". Masjid cordova dengan puncak menaranya yang indah, sekarang di ubah menjadi gereja katedral yang agung, istana Al Hamra di Granada dengan gaya arsitekturnya yang unik, istana ja'fariyah di Saragosa, tembok Toledo yang megah, istana Al-Ma'mun dan masjid Seville yang indah. ${ }^{29}$

\section{FAKTOR- FAKTOR PENDUKUNG KEMAJUAN}

Spanyol Islam, kemajuannya sangat di tentukan oleh adanya penguasa-penguasa yang kuat dan berwibawa, yang mampu mempersatukan kekuatan-kekuatan umat Islam, seperti Abd Al-Rahman Al-Dakhil,Abd Al-Rahman Al-Wasith dan Abd Al- Rahman Al-Nashir.

Keberhasilan politik pemimpin-pemimpin tersebut di tunjang oleh kebijaksanaan penguasa-penguasa lainnya yang mempelopori kegiatan-kegiatan ilmiah yang terpenting di antara penguasa dinasti umayyah di Spanyol dalam hal ini adalah Muhammad ibn Abd Al-Rahman (852-886) dan Al-Hakam II Al-Muntashir (961-976).

Toleransi beragama di tegakkan oleh para penguasa terhadap penganut agama kresten dan yahudi, sehingga mereka ikut berpartisipasi mewujudkan peradaban Arab Islam di Spanyol. Untuk orang kristen, sebagaimana juga orang-orang yahudi, di sediakan hakim khusus yang menangani masalah sesuai dengan ajaran agama mereka masing-masing. ${ }^{30}$

\section{KEMUNDURAN ISLAM DI SPANYOL}

Adapun sebab-sebab kemunduran dan kehancuran kekuasaan Islam di Spanyol antara lain yaitu:

1. Tidak Adanya Ideologi

\footnotetext{
${ }^{28}$ H. Taufiqurrahman, op. cit., hal 194.

${ }^{29} \mathrm{Ibid}$. hal 194-195.

${ }^{30}$ Badri yatim, op.cit., Hal 106.
} 
Masyarakat Islam Spanyol yang terdiri dari berbagai etnis dimana mula awal pembentukan kekuasaan ini sering timbul konflik, perselisihan, peperangan yang menggangu stabilitas politik, sosial dan ekonomi dinasti tersebut mereka terdiri dari bangsa Arab yang terdiri atas suku Qais (Arab utara) dan yaman (Arab selatan) suku barber yang terdiri atas golongan Bufr dan Brens; orang-orang yang disebut AlMuwalladun (penduduk Spanyol yang masuk Islam), orang-orang Saqolibah (budak Eropa yang di jadikan tentara bayaran). Konflik, sikap superioritas dan rasialis, fanatisme, ketidak puasan yang melahirkan pemberontakan bercampur-baur pada kekuasaan dinasti ini dimana mereka sulit disatukan dalam satu ideologi yang bermakna persatuan, apalagi tidak ada figure pemersatu. 31

2. Konflik Penguasa Muslim

Mereka sudah merasa puas dengan hanya menagih upeti dari kerajaan-kerajaan Kristen taklukannya dan membiarkan mereka mempertahankan hukum dan adat mereka, termasuk posisi hirarki tradisional, asal tidak ada perlawanan bersenjata. Hal itu menyebabkan kehidupan Negara Islam di Spanyol tidak pernah berhenti dari pertentangan antara Islam dan Kristen. Pada abad ke-11 M umat Kristen memperoleh kemajuan pesat, sementara umat Islam sedang mengalami kemunduran. ${ }^{32}$

3. Kesulitan ekonomi

Para penguasa membangun kota dan mengembangkan ilmu pengetahuan dengan sangat serius, sehingga lalai membina perekonomian. akibatnya timbul kesulitan ekonomi yang amat memberatkan dan mempengaruhi kondisi politik dan militer.

4. Tidak jelasnya sistem peralihan kekuasaan

Hal ini menyebabkan perebutan kekuasaan di antara ahli waris. Karena itulah kekuasaan bani ummayah runtuh dan Muluk Al-Thawaif muncul. Granada yang merupakan pusat kekuasaan Islam terakhir di Spanyol jatuh ke tangan Ferdinand dan Isabella. ${ }^{33}$

5. Keterpencilan

Spanyol Islam bagaikan terpencil dari dunia Islam yang lain. Ia selalu berjuang sendirian, tanpa mendapat bantuan kecuali dari afrika utara. Dengan demikian, tidak ada kekuasaan alternative yang mampu membendung kebangkitan Kristen di Spanyol. ${ }^{34}$

\footnotetext{
${ }^{31}$ H. Taufiqurrahman, op. cit., hal 188.

32 Dr. Badri Yatim, op. cit., Hal 107.

33 Ibid, hal 108.

34 Ibid, hal 108.
} 


\section{ANALISIS RUNTUHNYA ISLAM DI SPANYOL}

Periode penaklukan kembali Spanyol dimulai sejak jatuhnya kekhalifahan umayyah pada abad ke 11. Para sejarah Spanyol menganggap pertempuran covadonga tahun 718 di sini pemimpin Asturia, Pelayo, memukul mundur pasukan Islam sebagai tanda di mulainya penaklukan yang sesungguhnya. Pada abad 13 berlangsung dua proses penting kristenisasi dan penghabungan Spanyol. Menkristenisasi negeri itu tentu saja berbeda dengan mempersatukan, atau merebutnya kembali. Satu-satunya kawasan di semenanjung itu, tempat Islam berakar kuat adalah kawasan yang menjadi lahan pertumbuhan peradaban semit dan kartago. Di penghujung abad 13, di seluruh daratan itu, banyak kaum muslim yang telah tunduk pada Kristen melalui penaklukan maupun melalui perjanjian tetapi tetap mempertahankan hukum dan agama.

Adanya wilayah Kristen terdiri atas dua kerajaan, Castile dan aragon. Perkawinan antara Ferdinand dari Aragon dengan Isabella dari Castile pada 1469 telah mempersatukan dua kerajaan untuk selamanya. Penyatuan ini menjadi lonceng kematian bagi kekuasaan Islam di Spanyol. Kehancuran akhir dipercepat oleh kecerobohan sultan ke 19 Ali Abu Al- Hasan yang bukan hanya menolak membayar upeti yang sudah lazim, tetapi juga menyulut permusuhan dengan menyerang wilayah Castile. $^{35}$

Akan tetapi, kemajuan besar dalam peradaban ini, runtuh setelah dinasti yang berkuasa di wilayah kecil ini tidak mampu mencegah perebutan kekuasaan di kalangan pangeranya. Abu Abdullah Muhammad yang merasa di singkirkan karena tidak diberi wewenang menggantikan kedudukan bapaknya menjadi amir di Granada, akhirnya memberontak. Setelah ayahnya terbunuh kekuasaan beralih ke Muhammad ibn Sa'ad. Abu Abdullah meminta bantuan kepada Ferdinand dan Isabella. ${ }^{36}$ Ferdinand dan Isabella melihat bahwa tawaran Abu Abdullah, bisa di manfaatkan sebagai alat yang baik untuk membantu proses pemusnahan kerajaan Islam yang bernasib malang itu. Berbekal uang dan pasukan dari Castile, Abu Abdullah pada 1486 menduduki sebagian wilayah ibu kota yang di kuasai pamannya, dan untuk kedua kalinya ia menguasai Granada, yang kemudian memperlihatkan sebuah tontonan antik, yakni berperangnya dua sultan pada saat yang bersamaan, dalam sebuah perang saudara yang sengit. Legenda tentang penghancuran keluarga bangsawan patriotic Banu Sarraj di Alhambra

35 Philip K. Hitti, History of the Arabs, terbitan Palgrave Macmillan, Jakarta, 2002, hal 703.

${ }^{36}$ H. Taufiqurrahman, Sejarah Politik Masyarakat Islam, Bina Usaha Yogyakarta: 2001, hal 187 
oleh Abu Abdullah itu, untuk masa sekarang terdapat dalam sejarah mitis tentang harihari terakhir Granada.

Sementara itu, balatentara Castile sedang bergerak maju. Satu demi satu, kota-kota berjatuhan ke tangan mereka. Malaga direbut pada tahun berikutnya dan banyak penduduk yang di jual dalam perbudakan. Kepungan mereka semakin menyempit ke sekitar ibukota yang sudah mati. Al-zaghall tidak berhasil menghadang laju pasukan Ferdinand, sementara Abu Abdullah berperan sebagai sekutu Ferdinand. Dalam keputusanya Al-Zaghall menyeru para raja muslim di afrika, tetapi ungkapannya gagal, karena mereka juga sedang sibuk berperang antara meraka sendiri. Akhirnya ia menyerah dan mundur, dan di sana ia menjalani hari-hari terakhirnya dalam penderitaan dan kemiskinan.

Tak lama setelah Al-Zaqhall di kalahkan, Abu Abdullah di minta oleh patronya (1490) agar menyerahkan kota yang di kuasainya. Karena terbesit keinginan untuk menjadi seorang pemimpin pemberani, Abu Abdullah menolak memenuhi permintaan itu. Pada tahun berikutnya Ferdinand beserta sepasukan tentara dengan 10.000 kuda kembali memasuki Granada ia menghancurkan ladang pertanian, dan kebun buahbuahan, kemudian mengepung benteng pertahanan terakhir Islam di Spanyol dengan sangat rapat. Pengepungan itu di tekan lebih rapat membentuk sebuah blockade dengan maksud memaksa kota itu agar menyerah. ${ }^{37}$

Akhirnya pasukan muslim sepakat untuk menyerah, dan diberi jangka waktu dua bulan dengan syarat-syarat, Sultan beserta seluruh pejabatnya mesti mengucapkan sumpah setia kepada raja-raja Castile Abu Abdullah akan menerima sebidang tanah di Al-Basyarat, orang Islam akan di jamin keamananyan secara pribadi di bawah hukum mereka, dan bebas menjalankan agamanya. Ketika periode genjatan senjata berakhir, dan tidak ada tanda-tanda serangan dari orang Turki atau afrika, orang Castile mulai memasuki Granada pada 2 januari 1492. Abu Abdullah mulanya tinggal di tanah yang telah di jatahkan untuknya, tetapi kemudian pergi memencilkan diri ke fes,sampai kematian menjemputnya pada 1533.

Raja tertinggi mereka, Ferdinand dan Isabella, melanggar syarat-syarat kesepakatan perlindungan. Di bawah kepemimpinan pendeta yang dipercayai sang ratu, cardinal Ximenez de Cisneros, sebuah kampanye untuk memaksa perpindahan agama di jalankan pada 1499. Cardinal itu awalnya berusaha menarik buku-buku Arab dari 
peredaran, yakni buku-buku tentang Islam, dengan cara membakarnya. Granada menjadi medan api unggun tempat pembakaran naskah-naskah Arab. ${ }^{38}$

Banyak orang yang mengadopsi nama Kristen sebagai nama publik tetapi menggunakan nama Arab secara pribadi. Pada awal 1501, di keluarkan sebuah dekrit kerajaan yang berbunyi bahwa semua muslim di Castile dan leon mesti memeluk agama Kristen, atau tidak mereka mesti meninggalkan Spanyol. Pada 1556, Philip II menetapkan sebuah hukum yang mewajibkan semua muslim untuk meninggalkan bahasa, peribadatan, institusi, dan cara hidup mereka. Perintah pengusiran terakhir ditandatangani oleh Philip III pada 1609, yang mengakibatkan deportasi secara paksa, hampir semua orang muslim di dataran Spanyol. Diceritakan bahwa sekitar setengah juta muslim mesti merasakan nasib yang sama, kemudian banyak orang muslim yang meninggalkan Spanyol lalu mendarat di pantai-pantai Afrika. ${ }^{39}$

\section{KESIMPULAN}

Spanyol merupakan tempat yang paling utama bagi Eropa dalam penyerapan ilmu pengetahuan yang dikembangkan umat Islam di sana serta peradabannya, baik dalam hubungan politik, sosial, maupun ekonomi dan peradaban antar negara. Orang-orang Eropa menyaksikan kenyataan bahwa Spanyol berada di bawah kekuasaan Islam jauh meninggalkan negara-negara tetangganya di Eropa, terutama dalam bidang pemikiran dan sains. Di samping itu juga peradabannya yakni bangunan-bangunan fisik lainya.

Selanjutnya dari wilayah Spanyol ini mengalir berbagai pengetahuan untuk memajukan dan memperbaiki segala ketinggalannya bahkan mencapai kejayaannya hingga abad ini sebagaimana yang kita alami saat ini.

Islam hanya berkuasa di Granada di bawah dinasti bani Ahmar, karena seluruh wilayah Spanyol telah direbut kembali oleh pasukan Kristen. Kemajuan besar dalam peradaban ini, runtuh setelah dinasti yang hanya berkuasa di wilayah kecil ini tidak mampu mencegah perebutan kekuasaan di kalangan pangeranya. Abu Abdullah Muhammad yang merasa di singkirkan karena tidak diberi wewenang menggantikan kedudukan orang tuanya menjadi amir di Granada, akhirnya Abu Abdullah memberontak. Setelah ayahnya terbunuh kekuasaan beralih ke Mahammad ibn Sa'ad. Abu Abdullah lalu meminta bantuan kepada Ferdinand dan Isabella. Mereka berhasil mengalahkan penguasa yang sah dan menjadikan Abu Abdullah naik tahta. Ketika kedua

\footnotetext{
${ }^{38}$ Ibid, hal 706

${ }^{39} \mathrm{Ibid}$, hal 706.
} 
raja tersebut bersatu untuk merebut kekuasaan terakhir umat Islam di Granada. Abu Abdullah tidak kuasa menahan serangan tersebut pada tahun 1492. Kekalahan membuatnya hijrah ke afrika utara dan dengan demikian berakhirlah kekuasaan Islam di Spanyol.

\section{BIBLIOGRAPHY}

Amin, Samsul Munir, sejarah peradaban Islam, sinar grafika offset, Jakarta : 2009.

Badri yatim, Sejarah Peradaban Islam Dirasah Islamiyah Ii, rajawali pers, Jakarta, 2008.

Hitti, Philip K, History Of The Arabs, PT serambi ilmu semesta, Jakarta: 2010.

Http://fadliyanur.multiply.com/journal/item/34, Diakses tanggal 02 januari 2011.

Ira M Lapidus, sejarah social umat Islam, Jakarta Rajawali 1999.

Nizar, Syamsul Sejarah Pendidikan Islam Menelusuri Jejak Sejarah Era Rasullah Sampai Indonesia, fajar interpratama offset, Jakarta: 2007.

Suwito, sejarah social pendidikan Islam, kencana, Jakarta: 2005.

Syalabi, A, sejarah dan kebudayaan Islam, pustaka alhusna: Jakarta, 1983.

Taufiqurrahman, Sejarah Politik Masyarakat Islam, Bina Usaha Yogyakarta: 2001.

W Montgomery Watt, kejayaan Islam. Yogya, Tiara Wacana, 1990.

Yatim, Badri sejarah peradaban Islam, PT Rajagrafindo persada, Jakarta, 2008. 